\title{
ANALISIS KELEMBAGAAN DAN STRATEGI PENINGKATAN DAYA SAING UMKM EMPING MELINJO DI KABUPATEN MAGETAN
}

\author{
Fajar Kurnia Mustaqim, Kusnandar, Agustono \\ Program Studi Agribisnis, Fakultas Pertanian, Universitas Sebelas Maret Surakarta \\ E-mail: fajarkm@student.uns.ac.id
}

\begin{abstract}
This study aims to analyze institutional melinjo chips MSMEs, identify internal and external factors, formulate strategies for improving the competitiveness of melinjo chips MSMEs, and prioritizing strategies for improving the competitiveness of melinjo chips MSMEs in Magetan regency. The research methods used include: Descriptive Analysis, SWOT Analysis, SWOT matrix, and AHP. The results showed that: (1) there are 4 structure of the supply chain in the distribution of products chips melinjo, and the main institutional sectors in improving the competitiveness of melinjo chips MSMEs, namely the public sector, voluntary sector and private sector; (2) identification of internal and external factors obtained strengths, weaknesses, opportunities and threats in improving the competitiveness of melinjo chips MSMEs; (3) matrix SWOT produced 10 alternative strategies to increase competitiveness; (4) priority strategy in improving the competitiveness of melinjo chips MSMEs is provide training and guidance to the next generation about the importance of business continuity that has quality products according to market demand, establish cooperation with suppliers to ensure the availability of raw materials; and improve product quality and maximum service to maintain consumer confidence.
\end{abstract}

Keywords: Melinjo Chips, Institutional, Competitiveness, SWOT, AHP

\begin{abstract}
Abstrak: Penelitian ini bertujuan untuk menganalisis kelembagaan UMKM emping melinjo, mengidentifikasi faktor internal dan eksternal, merumuskan strategi peningkatan daya saing UMKM emping melinjo, dan menentukan prioritas strategi peningkatan daya saing UMKM emping melinjo di Kabupaten Magetan. Metode penelitian yang digunakan adalah Analisis Deskriptif, Analisis SWOT, Matrik SWOT, dan AHP. Hasil penelitian menunjukkan bahwa: (1) terdapat 4 struktur rantai pasok dalam pendistribusian produk emping melinjo dan sektor utama kelembagaan dalam peningkatan daya saing UMKM emping melinjo adalah public sector, voluntary sector dan private sector; (2) identifikasi faktor internal dan eksternal menghasilkan kekuatan, kelemahan, peluang dan ancaman dalam peningkatan daya saing UMKM emping melinjo; (3) matriks SWOT menghasilkan 10 alternatif strategi dalam peningkatan daya saing; (4) prioritas strategi dalam peningkatan daya saing UMKM emping melinjo adalah mengadakan pelatihan dan pembinaan terhadap generasi penerus tentang pentingnya kelanjutan usaha yang memiliki produk berkualitas sesuai permintaan pasar, membangun kerjasama dengan pemasok untuk menjamin ketersediaan bahan baku dan meningkatkan kualitas produk dan pelayanan maksimal untuk menjaga kepercayaan konsumen.
\end{abstract}

Kata kunci : Emping melinjo, Kelembagaan, Daya Saing, SWOT, AHP

\section{PENDAHULUAN}

Pembangunan pertanian di Kabupaten Magetan merupakan prioritas pembangunan daerah yang mempunyai keunggulan komparatif sebagai daerah agraris. Sektor pertanian meliputi subsektor tanaman pangan dan hortikultura, peternakan, perikanan serta subsektor perkebunan. Sektor pertanian menyumbang sebagian besar PDRB Kabupaten Magetan. 
Sektor pertanian dapat menciptakan usaha dari hasil pertanian yang disebut agroindustri. UMKM emping melinjo merupakan salah satu agroindustri di Kabupaten Magetan. UMKM emping melinjo mempunyai nilai ekonomis yang cukup tinggi dan berprospek cerah untuk diusahakan serta mampu bertahan di tengah persaingan dengan industri makanan lain di Kabupaten Magetan dan produk emping melinjo dari daerah lain.

Pemasaran dari produk UMKM Emping Melinjo sendiri sebagian besar masih berada di Kabupaten Magetan dan beberapa kota lainnya di daerah Jawa Timur seperti Madiun, Mojoketo, Kediri dan Sidoarjo. Produk UMKM emping melinjo belum ada ragam, kualitas, kesinambungan pasokan, dan kuantitas yang sesuai dengan permintaan pasar, khususnya untuk tujuan pasar modern (supermarket/ hypermarket), industri pengolahan, konsumen institusi (hotel, restoran, rumah sakit), dan pasar ekspor. Permasalahan tersebut salah satunya disebabkan oleh kurangnya koordinasi antar pelaku agroindustri. Hal ini menyebabkan struktur kelembagaan UMKM emping melinjo menjadi rapuh sehingga daya saing UMKM emping melinjo pun menjadi lemah.

Kelembagaan terdiri dari tiga pilar yang saling mendorong, yaitu public sector (kelembagaan pemerintah), voluntary sector (kelembagaan komunitas), dan private sector (kelembagaan pasar) (Uphoff, 1986 dan Syahyuti, 2004). Masing-masing pilar kelembagaan memiliki peran yang berbeda sehingga saling mendorong dalam membangun sistem kelembagaan. Secara sederhana ketiganya mewakili kekuatan politik, sosial dan ekonomi.

Menurut Sri Susilo (2007) UMKM di Indonesia memiliki masalah utama yaitu rendahnya produktivitas. Hal tersebut berkaitan dengan rendahnya kualitas sumberdaya manusia usaha skala mikro, dan rendahnya kompetensi kewirausahaan usaha skala mikro. Di samping itu, UMKM menghadapi pula faktor-faktor yang masih menjadi kendala dalam peningkatan daya saing UMKM. Faktorfaktor termaksud adalah: 1) Terbatasnya terhadap akses permodalan, 2) Terbatasnya terhadap akses ke pasar, dan 3) Terbatas akses informasi mengenai sumberdaya dan teknologi.
Peningkatan daya saing UMKM emping melinjo di Kabupaten Magetan memerlukan analisis kelembagaan dan identifikasi faktor internal dan eksternal. Analisis kelembagaan meliputi identifikasi rantai pasok pendistribusian produk emping melinjo dan struktur kelembagaan yang berperan didalamnya dikelompokkan ke dalam tiga pilar kelembagaan sehingga menghasilkan performa kelembagaan. Identifikasi faktor internal dan eksternal yang berpengaruh dalam peningkatan daya saing UMKM emping melinjo. Melalui analisis kelembagaan dan identifikasi faktor internal dan eksternal dapat ditentukan alternatif strategi dan prioritas strategi dalam peningkatan daya saing UMKM emping melinjo di Kabupaten Magetan.

Tujuan dari penelitian ini adalah menganalisis kelembagaan UMKM emping melinjo, mengidentifikasi faktor internal dan eksternal yang berpengaruh dalam peningkatan daya saing UMKM emping melinjo, merumuskan strategi peningkatan daya saing UMKM emping melinjo, dan menentukan prioritas strategi yang digunakan dalam peningkatan daya saing UMKM emping melinjo di Kabupaten Magetan.

\section{METODE PENELITIAN}

Metode dasar yang digunakan dalam penelitian ini adalah deskriptif analitis. Metode ini memusatkan perhatian pada pemecahan masalah-masalah yang ada dengan cara menyusun data-data yang telah terkumpul, menjelaskan, menganalisis, dan menyimpulkan dengan didukung oleh teori-teori yang ada dari hasil penelitian terdahulu (Surakhmad, 2004).

Penelitian ini dilakukan di Desa Purwosari Kecamatan Magetan Kabupaten Magetan. Pemilihan lokasi penelitian dilakukan secara purposive yaitu penentuan daerah sampel yang diambil secara sengaja. Desa Purwosari memiliki jumlah UMKM emping melinjo paling banyak yaitu 160 unit. Penelitian ini dilaksanakan selama tiga bulan mulai dari Juli-September 2016.

Responden yang digunakan adalah informan kunci (key informan) yang merupakan subjek yang telah cukup lama atau intensif menyatu pada objek yang akan diteliti, selain itu masih aktif pada kegiatan yang bersangkutan sehingga benar-benar paham dan 
mengetahui terkait hal-hal yang berhubungan dengan objek yang diteliti. Penelitian ini menggunakan metode Non Probability Sampling (pengambilan sampel non acak atau disengaja) dengan teknik Purposive Sampling untuk menentukan key informan yang memiliki kriteria (Nasution, 2003).

Responden yang dipilih sebagai informan kunci dalam penelitian ini yaitu: Produsen (UMKM emping melinjo), Kepala Bidang industri Dinas Perindustrian dan Perdagangan Kabupaten Magetan, Kepala Bidang UMKM Dinas Koperasi dan UMKM Kabupaten Magetan, Ketua Lembaga Keuangan Mikro (LKM) Mekar Sari Jaya, Ketua Kelompok Usaha Bersama (KUBE) Matahari dan Melati, serta pedagang pengecer atau lembaga pemasaran. Informasi dari informan kunci digunakan untuk menganalisis kelembagaan, mengidentifikasi faktor internal dan eksternal, dan kemudian merumuskan strategi peningkatan daya saing UMKM emping melinjo di Kabupaten Magetan. Setelah itu, peneliti menggunakan penilaian pakar yang memiliki pengetahuan khusus dalam bidang UMKM khususnya dalam hal peningkatan daya saing UMKM emping melinjo sebagai sampel dalam pengisian kuesioner perbandingan berpasangan untuk pemberian penilaian tingkat kepentingan kriteria dan alternatif strategi. Sampel yang dipilih sebagai pakar dalam pengisian kuesioner perbandingan berpasangan adalah: (1) Kepala Bidang industri Dinas Perindustrian dan Perdagangan Kabupaten Magetan, dan (2) Kepala Bidang UMKM Dinas Koperasi dan UMKM Kabupaten Magetan.

Analisis kelembagaan diawali dengan mengidentifikasi rantai pasok UMKM emping melinjo berdasarkan teori yang dikembangkan oleh Van der Vorst (2006) dan kemudian menganalisis struktur kelembagaan menurut Uphoff (1986) dan Syahyuti (2004). Dalam menganalisis kelembagaan menggunakan analisis deskriptif kualitatif.

Identifikasi faktor internal dan eksternal bertujuan untuk mengetahui faktor-faktor internal dan eksternal yang berpengaruh dalam peningkatan daya saing UMKM emping melinjo di kabupaten magetan. Untuk mengidentifikasi kekuatan dan kelemahan dari faktor internal serta peluang dan ancaman dari faktor eksternal dalam peningkatan daya saing UMKM emping melinjo di Kabupaten Magetan digunakan analisis SWOT. Analisis SWOT adalah identifikasi berbagai faktor secara sistematis untuk merumuskan strategi peningkatan daya saing UMKM emping melinjo.

Merumuskan strategi peningkatan daya saing UMKM emping melinjo di Kabupaten Magetan menggunakan matriks SWOT. Analisis SWOT digambarkan ke dalam matriks SWOT dan melihat performa kelembagaan hasil analisis kelembagaan, sehingga dengan empat kemungkinan alternatif strategi, yaitu strategi S-O, strategi W-O, strategi S-T, dan strategi W-T (Rangkuti, 2006).

Analisis prioritas strategi peningkatan daya saing UMKM emping melinjo menggunakan Analytical Hierarkie Process (AHP). Tujuannya untuk memperoleh prioritas strategi dari beberapa alternatif strategi yang dihasilkan dalam matriks SWOT untuk peningkatan daya saing UMKM emping melinjo di Kabupaten Magetan.

\section{HASIL DAN PEMBAHASAN}

\section{Analisis Kelembagaan UMKM Emping Melinjo di Kabupaten Magetan}

Kelembagaan merupakan fenomena sosial ekonomi yang berkaitan dengan hubungan antara dua atau lebih pelaku interaksis sosial ekonomi yang mencakup aturan-aturan yang disepakati oleh para pelaku interaksi, disertai analisis hasil akhir yang diperoleh dari interaksi yang terjadi (Taryoto, 1995). Analisis kelembagaan UMKM emping melinjo di Kabupaten Magetan yaitu menganalisis hubungan interaksi antar pelaku dalam rantai pasok.

Struktur rantai pasok produk pertanian menurut Marimin (2013) memiliki keunikan karena aliran rantai pasok mengalir sesuai kehendak pelaku usaha. Seperti petani dapat langsung menjual hasil pertaniannya langsung ke pasar selaku retail. Begitu juga dengan manufaktur atau agroindustri tidak harus memasok produk lewat distributornya ke retail tetapi bisa langsung ke konsumen.

Emping melinjo merupakan salah satu produk agroindustri di Kabupaten Magetan. Struktur rantai pasok produk agroindustri memiliki karakteristik yang berbeda-beda, termasuk emping melinjo. Perbedaan utama sistem distribusi produk agroindustri terdapat 
pada jenis produk dan kualitas yang dihasilkan. Jenis atau kualitas produk emping melinjo yang distribusikan sesuai dengan permintaan di masing-masing tempat tujuan distribusi.

Ada tiga macam aliran yang harus dikelola dalam suatu rantai pasok. Pertama adalah aliran barang yang sudah terjadi secara kontinu pada tingkat produsen (UMKM emping melinjo) ke konsumen akhir. Kedua adalah aliran finansial/uang dari konsumen akhir ke produsen. Ketiga adalah aliran informasi yang sudah optimal dan terbuka, dapat mengalir dari produsen ke konsumen akhir atau sebaliknya. Aliran barang, uang dan informasi pada
UMKM emping melinjo di Kabupaten Magetan umumnya mengikuti pola yang ditunjukkan dalam Gambar 1.

Struktur rantai pasok dapat dianalisis dengan metode deskriptif-kualitatif yang dikembangkan oleh Van der Vorst (2006). Analisis ini berdasarkan pendapat dari narasumber berdasarkan aspek-aspek pada struktur rantai, sasaran rantai, manajemen rantai, sumber daya rantai dan proses bisnis rantai pasok emping melinjo. Analisis kondisi rantai pasok UMKM emping melinjo di Kabupaten Magetan secara ringkas dapat dilihat pada Tabel 1.

\begin{tabular}{|c|c|c|}
\hline${ }^{1)}$ Produsen & 4 & Konsumen \\
\hline${ }^{2)}$ Produsen & 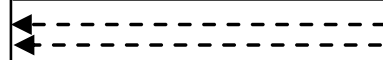 & Pasar Lokal \\
\hline${ }^{3)}$ Produsen & Pengumpul & Pasar Lokal \\
\hline${ }^{4)}$ Produsen & Pengumpul & ar Luar Kabu \\
\hline
\end{tabular}

Keterangan :

Aliran barang

Aliran uang

Aliran informasi

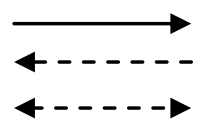

Gambar 1. Struktur Aliran Rantai Pasok Emping Melinjo

Tabel 1. Analisis Kondisi Rantai Pasok UMKM Emping Melinjo di Kabupaten Magetan

\begin{tabular}{|c|c|}
\hline Analisis Deskriptif & UMKM Emping Melinjo \\
\hline Struktur Rantai & $\begin{array}{l}\text { Anggota rantai pasok terdiri dari produsen (UMKM emping melinjo), distributor } \\
\text { (pedagang pengumpul, pedagang pasar), Pasar sebagai konsumen, dan Konsumen }\end{array}$ \\
\hline Sasaran Rantai & $\begin{array}{l}\text { Sasaran pengembangan rantai pasok adalah memperluas saluran distribusi mulai } \\
\text { ke banyak kabupaten hingga provinsi, serta menambah mitra usaha. }\end{array}$ \\
\hline Manajemen Rantai & $\begin{array}{l}\text { 1. Kerja sama dan pemilihan mitra antar pelaku rantai masih didasarkan pada } \\
\text { asas kekeluargaan dan kepercayaan. } \\
\text { 2. Kesepakatan kontraktual belum tersedia }\end{array}$ \\
\hline Sumber Daya Rantai & $\begin{array}{l}\text { Jumlah unit UMKM emping melinjo di Kabupaten Magetan adalah } 268 \text { unit, } \\
\text { dengan tenaga kerja } 402 \text { orang dan hasil produksi Rp 29.371.303.300 } \\
\text { (Disperindag, 2015). }\end{array}$ \\
\hline Proses Bisnis Rantai & $\begin{array}{l}\text { 1. Pola distribusi mengikuti pola distributor storage with package carrier } \\
\text { delivery (Emping melinjo dikirim kepada konsumen melalui jasa pedagang } \\
\text { pengumpul) } \\
\text { 2. Pola distribusi langsung antara produsen langsung ke konsumen dan produsen } \\
\text { ke pasar sebagai konsumen akhir }\end{array}$ \\
\hline
\end{tabular}

Sumber : Analisis Data Primer 2016 
Berdasarkan hasil penelitian, struktur rantai pasok yang paling dominan digunakan adalah struktur rantai 4 dimana produsen menjual produk emping melinjo kepada pedagang pengumpul, kemudian pedagang pengumpul mendistribusikannya ke pasar-pasar di luar Kabupaten Magetan. Produsen menyukai struktur rantai 4 karena biaya pengangkutan ditanggung oleh pedagang pengumpul. Selain itu memiliki jaringan pasar yang luas dan diakui produsen bahwa volume penjualan produk emping melinjo lebih tinggi. Tingginya volume penjualan pada struktur ini menunjukkan tingginya kontinuitas pendistribusian sehingga struktur ini dinilai sebagai alternatif struktur yang efisien.

Kelembagaan sangat dibutuhkan dalam pengembangan usaha produk pertanian, khususnya dalam melakukan kerjasama yang terintegrasi antara produsen dengan pelaku mitra usaha agar produk yang dihasilkan memiliki daya saing yang tinggi. Menurut Syahyuti (2004) dan Uphoff (1986), kelembagaan memiliki tiga pilar utama, yang satu sama lain saling mempengaruhi dan ikut mewarnai bentuk sistem kelembagaan. Ketiga pilar tersebut adalah public sector (pemerintah) yang tersusun dari administrasi lokal dan pemerintah lokal, voluntary sector (komunitas) yang tersusun dari kelembagaan yang anggotanya masyarakat lokal dan kerjasama usaha, dan private sector (pasar) yang tersusun dari lembaga pelayanan dan bisnis swasta. Secara sederhana ketiganya direpresentasikan sebagai kekuatan politik, sosial, dan ekonomi yang harus kerjasama serta bersinergis

\section{Public sector}

Aktor yang sebagai public sector adalah Dinas Perindustrian dan Perdagangan Kabupaten Magetan dan Dinas Koperasi dan UMKM Kabupaten Magetan. Kelembagaan pemerintah merupakan wadah untuk berjalannya voluntary sector dan private sector. Dimana aktor-aktor voluntary sector dan private sector dapat berinteraksi dalam akses dan distribusi manfaat terhadap sumber daya yang ada. Peran dari Pemerintah Kabupaten Magetan bagi UMKM emping melinjo adalah sebagai fasilitator dan katalisator.

Pemerintah sebagai fasilitator memiliki peran dalam memfasilitasi UMKM emping melinjo untuk mencapai tujuan pengembangan dan peningkatan daya saing. Jika UMKM mempunyai kelemahan, tugas fasilitator adalah memberi kemampuan UMKM dengan berbagai cara dan membantu mencari jalan keluar (Diva, 2009). Hal tersebut dilakukan Pemerintah Kabupaten Magetan dengan mengadakan pelatihan, pendampingan dan fasilitasi kelembagaan usaha yang dilaksanakan oleh Dinas Perindustrian dan Perdagangan serta Dinas Koperasi dan UMKM Kabupaten Magetan. Pelatihan dan pendampingan yang diberikan kepada pelaku UMKM emping melinjo berupa pemberian wawasan alur proses produksi pengolahan, dan pembukuan sederhana. Diberikan juga pelatihan wirausaha baru, yakni pelatihan pengolahan melinjo menjadi produk emping melinjo yang berkualitas sesuai dengan permintaan pasar. Selain melakukan pelatihan dan pendampingan, pemerintah Kabupaten Magetan juga melakukan fasilitasi dalam bidang kelembagaan usaha serta sarana dan prasarana berupa bantuan peralatan berupa wajan, kompor, dan alat menempa.

Pemerintah Kabupaten Magetan berperan sebagai katalisator, yaitu pemerintah memberikan suatu pendorong untuk mempercepat pengembangan dan peningkatan daya saing UMKM emping melinjo. Untuk dapat menjalakan perannya sebagai katalisator, Pemerintah Kabupaten Magetan melakukan berbagai langkah seperti memberikan informasi bagi UMKM emping melinjo terkait program bantuan permodalan, sehingga dapat diakses dengan mudah. Selain itu pemerintah Kabupaten Magetan melakukan pendataan jumlah produk emping melinjo yang diproduksi dan pendapatan UMKM emping melinjo di Kabupaten Magetan yang nantinya digunakan untuk menarik investor memberikan akses permodalan. Peranan sebagai katalisator juga dalam kegiatan promosi produk emping melinjo. Promosi produk emping melinjo dilakukan dengan menggelar pameran dengan disertai menampilkan produk lainnya dari Kabupaten Magetan. Kegiatan promosi ini untuk lebih memperluas jangkauan pasar dari produk emping melinjo, sehingga UMKM emping melinjo Kabupaten Magetan dapat bersaing dengan produk emping melinjo dari daerah lainnya. 


\section{Voluntary sector}

Aktor yang sebagai voluntary sector adalah LKM (Lembaga Keuangan Mikro) Mekar Sari Jaya, Produsen (UMKM emping melinjo), dan Kelompok usaha bersama (KUBE). Peran dari kelembagaan komunitas adalah penghubung anatara public sector dan private sector. Hal tersebut dilakukan produsen (UMKM emping melinjo) maupun KUBE dengan membangun kerjasama dengan kelembagaan pemerintah dan kelembagaan pasar. Kerjasama yang dibangun dengan pemerintah Kabupaten Magetan untuk mendorong berkembangnya UMKM emping melinjo di Kabupaten Magetan melalui peningkatan jumlah dan kualitas sumber daya manusia sehingga dapat meningkatkan daya saing UMKM. Kerjasama yang dibangun dengan kelembagaan pasar berpegang pada model kerjasama yang saling menguntungkan. Produsen mendistribusikan produk emping melinjo kepada pedagang pengumpul, pasar lokal, maupun pasar luar kabupaten.

Selain sebagai penghubung anatara public sector dan private sector, kelembagaan komunitas juga berperan menciptakan kekayaan sosial, dimana keuntungan yang diperoleh diinvestasikan kembali ke dalam masyarakat. Hal tersebut dilakukan oleh produsen melalui wadah KUBE membentuk LKM (Lembaga Keuangan Mikro) dengan harapan dapat memfasilitasi keperluan KUBE melalui simpan pinjam. Sistem simpan pinjam dalam LKM ini berdasarkan sistem bagi hasil yang telah disepakati bersama anggota. Sebagai wujud dari rasa tanggungjawab sosial dan kepedulian sosial anggota KUBE, setiap bulannya mengadakan pengguliran dana Iuran Kesetiakawanan Sosial (IKS) kepada masyarakat miskin di sekitar KUBE yang mempunyai usaha emping melinjo sebanyak 1 orang dan penerima pengguliran tersebut mengikuti kegiatan KUBE.

\section{Private sector (kelembagaan pasar)}

Aktor yang sebagai Private sector (kelembagaan pasar) adalah Lembaga keuangan formal, Lembaga keuangan non formal (pedagang), pemasok melinjo, pengumpul, dan pasar. Peran dari kelembagaan pasar adalah penunjang terlaksananya program dan layanan dalam peningkatan daya saing UMKM emping melinjo di Kabupaten Magetan, membantu mengatasi masalah mengenai produksi, pendistribusian atau pelayanan suatu jasa yang di perlukan dalam mendukung peningkatan daya saing. Hal itu dilakukan kelembagaan pasar dengan melakukan penyediaan pinjaman modal uang maupun modal bahan baku.

Peminjaman modal berupa uang disediakan oleh Lembaga keuangan formal dan non formal (pedagang). Akses UMKM emping melinjo terhadap lembaga keuangan formal relatif kecil, karena lembaga keuangan formal memiliki prosedur yang relatif sulit dan bunga relatif tinggi. UMKM emping melinjo di Kabupaten Magetan lebih memilih melakukan peminjaman modal kepada lembaga keuangan non formal (pedagang) yang transaksi peminjamannya mudah.

Peminjaman modal berupa bahan baku disediakan oleh pemasok melinjo. Pemasok melinjo berasal dari dalam dan luar Kabupaten Magetan. Dalam transaksi peminjaman belum ada kesepakatan kontraktual, hanya berdasarkan asas kekeluargaan dan kepercayaan. Sebagian Pemasok melinjo juga sebagai pemasaran produk emping melinjo.

Tabel 2. Identifikasi Faktor Internal pada Peningkatan Daya Saing UMKM Emping Melinjo di Kabupaten Magetan

\begin{tabular}{|c|c|c|}
\hline Faktor Internal & Kekuatan & Kelemahan \\
\hline Kondisi Keuangan & & - Modal usaha masih terbatas \\
\hline Pemasaran & $\begin{array}{l}\text { - Produk tahan lama } \\
\text { - Harga produk yang terjangkau } \\
\text { - Produk berkualitas }\end{array}$ & $\begin{array}{l}\text { - Tidak adanya merk dagang } \\
\text { - Belum ada packaging }\end{array}$ \\
\hline Produksi & - Kontinuitas hasil & - Kapasitas produksi belum maksimal \\
\hline $\begin{array}{l}\text { Sumber Daya } \\
\text { Manusia }\end{array}$ & - KUBE berprestasi di tingkat provinsi & $\begin{array}{l}\text { - Jumlah dan kualitas SDM kurang } \\
\text { memadai }\end{array}$ \\
\hline
\end{tabular}

Sumber: Analisis Data Primer, 2016 
Identifikasi Faktor Internal dan Eksternal Faktor internal merupakan lingkungan dalam UMKM emping melinjo yang mampu dikendalikan oleh pelaku usaha yang mencakup kekuatan dan kelemahan yang ada di UMKM emping melinjo di Kabupaten Magetan dalam melakukan peningkatan daya saing. Berdasarkan hasil identifikasi terhadap faktor internal, didapatkan kekuatan dan kelemahan bagi UMKM emping melinjosebagai berikut yang ditampilkan pada Tabel 2 .

Faktor eksternal merupakan lingkungan luar yang tidak mampu dikendalikan sendiri yang mencakup peluang dan ancaman yang ada di UMKM emping melinjo di Kabupaten Magetan dalam melakukan peningkatan daya saing. Berdasarkan hasil identifikasi terhadap faktor eksternal, didapatkan peluang dan ancaman bagi UMKM emping melinjo sebagai berikut yang ditampilkan pada Tabel 3 .

\section{Perumusan Strategi Peningkatan Daya Saing UMKM Emping Melinjo}

Untuk merumuskan alternatif strategi pengembangan UMKM emping melinjo di Kabupaten Magetan digunakan analisis matriks SWOT. Matriks SWOT dapat menggambarkan secara jelas bagaimana peluang dan ancaman dari faktor eksternal yang dihadapi oleh suatu usaha dapat disesuaikan dengan kekuatan dan kelemahan yang dimiliki. Analisis SWOT digambarkan ke dalam matriks SWOT dengan 4 kemungkinan alternatif strategi, yaitu stategi kekuatan-peluang (S-O), strategi kelemahanpeluang (W-O), strategi kekuatan-ancaman (ST), dan strategi kelemahan-ancaman (W-T).

Setelah menganalisis kelembagaan pada UMKM emping melinjo dan mengidentifikasi faktor-faktor internal dan eksternal yang menjadi kekuatan dan kelemahan serta peluang dan ancaman dalam meningkatkan daya saing UMKM emping melinjo di Kabupaten Magetan, maka diperoleh beberapa alternatif strategi yang dapat dipertimbangkan. Untuk lebih jelasnya dapat dilihat pada Tabel 4 .

Tabel 3. Identifikasi Faktor-faktor Eksternal pada Peningkatan Daya Saing UMKM Emping Melinjo di Kabupaten Magetan

\begin{tabular}{|c|c|c|}
\hline Faktor Eksternal & Peluang & Ancaman \\
\hline $\begin{array}{l}\text { Kondisi } \\
\text { Perekonomian }\end{array}$ & $\begin{array}{l}\text { - Adanya lembaga keuangan yang } \\
\text { menyediakan pinjaman modal. }\end{array}$ & \\
\hline Sosial dan Budaya & $\begin{array}{l}\text { - Permintaan meningkat pada musim } \\
\text { tertentu } \\
\text { - Memiliki hubungan yang baik } \\
\text { dengan pemasok, konsumen dan } \\
\text { distributor. } \\
\text { - Memiliki pelanggan tetap }\end{array}$ & - \\
\hline Pemerintah & & $\begin{array}{l}\text { - Kurang bimbingan dan pengawan } \\
\text { pemerintah } \\
\text { - Pelaksanaan penyuluhan belum } \\
\text { optimal. }\end{array}$ \\
\hline Persaingan & & $\begin{array}{l}\text { - Adanya pesaing emping melinjo dari } \\
\text { daerah lain } \\
\text { - Persaingan dengan produk makanan } \\
\text { lain }\end{array}$ \\
\hline Teknologi & $\begin{array}{l}\text { - Perkembangan teknologi informasi } \\
\text { dan komunikasi }\end{array}$ & \\
\hline
\end{tabular}


Tabel 4. Alternatif Strategi Matriks SWOT Peningkatan Daya Saing UMKM Emping Melinjo di Kabupaten Magetan

\begin{tabular}{|c|c|c|}
\hline Ekternal & $\begin{array}{l}\text { Kekuatan (S) } \\
\text { 1. Produk emping melinjo yang } \\
\text { berkualitas } \\
\text { 2. Produk emping melinjo tahan } \\
\text { lama } \\
\text { 3. Kontinuitas produk emping } \\
\text { melinjo } \\
\text { 4. Kelompok usaha bersama } \\
\text { (KUBE) berprestasi di } \\
\text { tingkat provinsi } \\
\text { 5. Harga produk emping } \\
\text { melinjo yang terjangkau }\end{array}$ & $\begin{array}{l}\text { Kelemahan (W) } \\
\text { 1. Modal usaha yang masih terbatas } \\
\text { 2. Jumlah dan kualitas SDM kurang } \\
\text { memadai } \\
\text { 3. Kapasitas produksi yang belum } \\
\text { maksimal } \\
\text { 4. Tidak adanya merk dagang } \\
\text { 5. Tidak tersedianya proses } \\
\text { packcaging }\end{array}$ \\
\hline $\begin{array}{l}\text { Peluang }(\mathbf{O}) \\
\text { 1. Permintaan terhadap } \\
\text { produk emping melinjo } \\
\text { meningkat pada musim } \\
\text { tertentu. } \\
\text { 2. Memiliki pelanggan tetap } \\
\text { 3. Memiliki hubungan yang } \\
\text { baik dengan pemasok, } \\
\text { konsumen dan distributor } \\
\text { 4. Adanya lembaga } \\
\text { keuangan yang } \\
\text { menyediakan pinjaman } \\
\text { uang. } \\
\text { 5. Perkembangan teknologi } \\
\text { informasi dan } \\
\text { komunikasi }\end{array}$ & $\begin{array}{l}\text { Strategi SO } \\
\text { 1. Meningkatkan kualitas } \\
\text { produk dan pelayanan yang } \\
\text { maksimal untuk menjaga } \\
\text { kepercayaan konsumen . (S1, } \\
\text { S2, S3, S4, S5, O1, O2, O5) } \\
\text { 2. Meningkatkan kapasitas } \\
\text { produsen dan kelembagaan } \\
\text { KUBE dalam menjalin } \\
\text { kerjasama kemitraan. (S4, } \\
\text { O3, O4, O5) }\end{array}$ & $\begin{array}{l}\text { Strategi WO } \\
\text { 1. Mengadakan pelatihan dan } \\
\text { pembinaan terhadap generasi } \\
\text { penerus akan pentingnya kelanjutan } \\
\text { usaha yang memiliki produk } \\
\text { berkualitas sesuai permintaan pasar. } \\
\text { (W2, W4, W5, O1, O2, O3, O5) } \\
\text { 2. Pemanfaatan pinjaman lembaga } \\
\text { keuangan untuk meningkatkan } \\
\text { modal pengembangan UMKM } \\
\text { emping melinjo. (W1, W3, O2, O4, } \\
\text { O5) } \\
\text { 3. Meningkatkan kapasitas produksi } \\
\text { emping melinjo untuk memenuhi } \\
\text { permintaan konsumen. (W1, W3, } \\
\text { O1, O2, O3, O4) }\end{array}$ \\
\hline $\begin{array}{l}\text { Ancaman (T) } \\
\text { 1. Fluktuasi harga bahan } \\
\text { baku. } \\
\text { 2. Sebagian besar bahan } \\
\text { baku dipasok dari luar } \\
\text { daerah. } \\
\text { 3. Pelaksanaan Penyuluhan } \\
\text { yang belum optimal } \\
\text { 4. Kurang bimbingan dan } \\
\text { pengawasan pemerintah } \\
\text { 5. Adanya pesaing emping } \\
\text { melinjo dari daerah lain. }\end{array}$ & $\begin{array}{l}\text { Strategi ST } \\
\text { 1. Membuat kebijakan } \\
\text { pemerintah yang mendukung } \\
\text { peningkatan daya saing } \\
\text { UMKM emping melinjo. (S1, } \\
\text { S2, S3, S4, T1, T2, T3, T4, } \\
\text { T5) } \\
\text { 2. Memperluas jaringan } \\
\text { distribusi dan pemasaran ke } \\
\text { luar kabupaten Magetan. (S1, } \\
\text { S2, S3, S4, T1, T2, T5) }\end{array}$ & $\begin{array}{l}\text { Strategi WT } \\
\text { 1. Menambah merk dagang dan proses } \\
\text { packaging pada produk emping } \\
\text { melinjo. (W4, W5, T1, T2, T5) } \\
\text { 2. Peningkatan kerjasama antara } \\
\text { produsen dengan pemasok untuk } \\
\text { menjamin ketersediaan bahan baku. } \\
\text { (W1, W3, W4, W5, T1, T2,T5) } \\
\text { 3. Mengembangan program } \\
\text { pendampingan berkala UMKM dan } \\
\text { Kelembagaan. (W1, W2, W3, W4, } \\
\text { T3, T4) }\end{array}$ \\
\hline
\end{tabular}

Sumber : Analisis Data Primer 2016

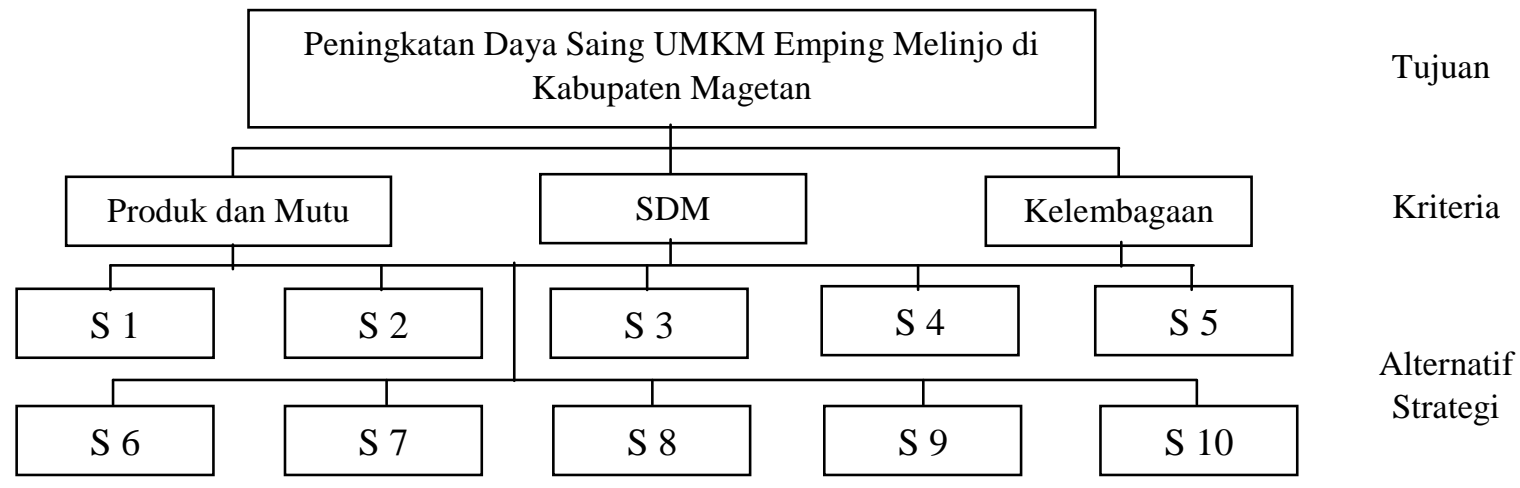

Gambar 2. Hierarki Model Strategi Peningkatan Daya Saing UMKM Emping Melinjo di Kabupaten Magetan 
Analisis AHP pada tingkat pertama menghasilkan prioritas dari kriteria dalam mencapai tujuan peningkatan daya saing UMKM emping melinjo di Kabupaten

\section{Prioritas Strategi Peningkatan Daya Saing UMKM Emping Melinjo}

Tahap pengambilan keputusan dari berbagai strategi hasil SWOT ditentukan prioritasnya menggunakan AHP. Metode AHP merupakan teknik yang secara obyektif untuk memilih strategi alternatif secara prioritas dari berbagai alternatif strategi yang telah dirumuskan dengan metode SWOT. Berdasarkan hasil kuisioner dan analisis menggunakan Expert Choice dihasilkan hierarki pada Gambar 2. Magetan adalah kriteria sumber daya manusia (0.434), kriteria produk dan mutu (0.426) dan kriteria kelembagaan (0.140). Hal ini menggambarkan bahwa kriteria sumber daya manusia merupakan kriteria yang memiliki peran penting dalam mencapai peningkatan daya saing UMKM emping melinjo di Kabupaten Magetan.

Tabel 5. Tingkatan Prioritas alternatif strategi peningkatan daya saing UMKM emping melinjo di Kabupaten Magetan

\begin{tabular}{llc}
\hline \multicolumn{1}{c}{ Kriteria } & Bobot & Prioritas \\
\hline Strategi 1 & 0.124 & 3 \\
Strategi 2 & 0.106 & 6 \\
Strategi 3 & $\mathbf{0 . 1 3 7}$ & $\mathbf{1}$ \\
Strategi 4 & 0.043 & 10 \\
Strategi 5 & 0.103 & 7 \\
Strategi 6 & 0.110 & 5 \\
Strategi 7 & 0.071 & 8 \\
Strategi 8 & 0.060 & 9 \\
Strategi 9 & 0.125 & 2 \\
Strategi 10 & 0.121 & 4 \\
\hline
\end{tabular}

Sumber: Analisis Data Primer 2016

Hasil analisis AHP secara keseluruhan dengan kriteria produk dan mutu, sumber daya manusia, serta kelembagaan diperoleh skala prioritas strategi peningkatan daya saing UMKM emping melinjo di Kabupaten magetan sebagai berikut:

1) Mengadakan pelatihan dan pembinaan terhadap generasi penerus akan pentingnya kelanjutan usaha yang memiliki produk berkualitas sesuai permintaan pasar (S3) $(0,137)$.
2) Peningkatan kerjasama antara produsen dengan pemasok untuk menjamin ketersediaan bahan baku (S9) $(0,125)$.

3) Meningkatkan kualitas produk dan pelayanan yang maksimal untuk menjaga kepercayaan konsumen (S1) $(0,124)$.

4) Pengembangan program pendampingan UMKM dan Kelembagaan. (S10) $(0,121)$.

5) Membuat kebijakan pemerintah yang mendukung peningkatan daya saing UMKM emping melinjo (S6) $(0,110)$.

6) Meningkatkan kapasitas produsen dan kelembagaan KUBE dalam menjalin kerjasama kemitraan (S2) $(0,106)$.

7) Meningkatkan kapasitas produksi emping melinjo untuk memenuhi permintaan konsumen (S5) (0,103).

8) Memperluas jaringan distribusi dan pemasaran ke luar kabupaten Magetan (S7) $(0,071)$.

9) Menambah merk dagang dan packaging produk emping melinjo (S8) $(0,060)$.

10) Pemanfaatan pinjaman lembaga keuangan untuk meningkatkan modal pengembangan UMKM emping melinjo (S4) $(0,043)$.

\section{KESIMPULAN DAN SARAN}

\section{Kesimpulan}

Terdapat empat struktur aliran rantai pasok dan tiga pilar kelembagaan dalam UMKM emping melinjo di Kabupaten Magetan, yaitu public sector terdiri dari Disperindag dan Diskopumkm yang memiliki peran sebagai fasilitator dan katalisator. Voluntary sector terdiri dari LKM, Produsen/pemilik UMKM, dan KUBE yang memiliki peran sebagai penghubung antara public sector dan private sector, serta menciptakan kekayaan sosial. Sedangkan private sector terdiri dari lembaga keuangan formal, lembaga keuangan non formal, pemasok melinjo, pengumpul, dan pasar yang memiliki peran sebagai penunjang terlaksananya program dan layanan dalam mendukung peningkatan daya saing.

Identifikasi faktor internal dan eksternal menunjukkan bahwa kekuatan meliputi produk emping melinjo yang berkualitas, produk tahan lama, kontinuitas produk, KUBE berprestasi, dan harga produk terjangkau, kelemahan meliputi modal usaha yang terbatas, jumlah dan kualitas SDM kurang memadai, kapasitas produksi belum maksimal, tidak adanya merk 
dagang, dan packaging, peluang meliputi:permintaan terhadap produk emping melinjo meningkat pada musim tertentu, memiliki pelanggan tetap, memiliki hubungan yang baik dengan pemasok, konsumen dan distributor, adanya lembaga keuangan yang menyediakan pinjaman modal, dan perkembangan teknologi informasi dan komunikasi, dan ancaman meliputi fluktuasi harga bahan baku, sebagian besar bahan baku dari luar daerah, penyuluhan belum maksimal, kurang bimbingan dan pengawasan pemerintah, adanya persaingan emping melinjo daerah lain.

Matriks SWOT menghasilkan 10 alternatif strategi yang dapat digunakan dalam upaya peningkatan daya saing UMKM emping melinjo di Kabupaten Magetan.

Analytical Hierarchy Process (AHP) menggunakan software Expert Choice 11 menyimpulkan bahwa sumber daya manusia sebagai kriteria yang paling penting. Prioritas strategi peningkatan daya saing UMKM emping melinjo di Kabupaten Magetan adalah: a) Mengadakan pelatihan dan pembinaan terhadap generasi penerus akan pentingnya kelanjutan usaha yang memiliki produk yang berkualitas, b) Peningkatan kerjasama antara produsen dengan pemasok untuk menjamin ketersediaan bahan baku, dan c) Meningkatkan kualitas produk dan pelayanan yang maksimal untuk menjaga kepercayaan konsumen.

\section{Saran}

Berdasarkan hasil penelitian, maka disarankan Dinas Perindustrian dan Perdagangan Kabupaten Magetan hendaknya membuat kebijakan dan program pengawasan kerjasama kemitraan dan persaingan yang sehat, serta memfasilitasi dalam pelatihan dan pemasaran UMKM emping melinjo di Kabupaten Magetan, Dinas Koperasi dan UMKM Kabupaten Magetan hendaknya menumbuh kembangkan LKM dan melakukan pendampingan UMKM emping melinjo di Kabupaten Magetan, kelembagaan di tingkat produsen/ Kelompok usaha bersama (KUBE) hendaknya mengelola dengan baik Lembaga Keuangan Mikro (LKM) dimulai dengan pengelolaan dana bantuan dari pemerintah dengan efektif dan efisien sehingga dapat berkembang sebagai penunjang modal simpanpinjam secara sederhana di tingkat produsen., kelembagaan pasar hendaknya menjaga dan meningkatkan kerjasama yang saling menguntungkan serta saling membutuhkan dengan UMKM emping melinjo di Kabupaten Magetan.

\section{DAFTAR PUSTAKA}

Badan Pusat Statistik Kabupaten Magetan. 2015. Magetan dalam Angka Tahun 2015.

Diva, G. 2009. Mengembangkan UKM Melalui Pemberdayaan Peran Pemerintah Daerah Jakarta. Jakarta: Bakrie School of Management.

Rangkuti, A.H. 2011. Teknik Pengambilan Keputusan Multi Kriteria Menggunakan Metode Bayes, MPE, CPI dan AHP. Jurnal. Vol.2 No. 1 Juni 2011: 229-238. Jakarta: Binus University.

Marimin, M. 2013. Aplikasi Teknik Pengambilan Keputusan dalam Manajemen Rantai Pasok. Bogor: IPB Press.

Rangkuti, F. 2006. Analisis swot teknik membedah kasus bisnis Reorientasi konsep perencanaan strategis untuk menghadapi abad 21. Jakarta: Gramedia Pustaka Utama.

Saaty, T.L. 1991. Pengambilan Keputusan Bagi Para Pemimpin, Proses Hirarki Analitik untuk Pengambilan Keputusan dalam Situasi yang Kompleks. Jakarta: Pustaka Binama Pressindo.

Sri Susilo, Y. 2007. Pertumbuhan Usaha Industri Kecil dan Menengah (IKM) dan Faktor-faktor yang Mempengaruhinya. Eksekutif. 4(2): 306 - 313.

Syahyuti. 2003. Bedah konsep kelembagaan strategi pengembangan dan penerapannya dalam penelitian pertanian. Bogor: Pusat penelitian dan pengembangan sosial ekonomi.

Syahyuti. 2004. Pemerintah, Pasar, dan Komunitas: Faktor Utama dalam Pengembangan Agribisnis di Pedesaan. Forum Penelitian Agro Ekonomi. 22(1): 54-62. Bogor : Pusat penelitian dan pengembangan sosial ekonomi pertanian. 
Fajar K. M., Kusnandar, Agustono: Analisis Kelembagaan dan Strategi ....

Uphoff, N.T. 1986. Local Institutional Development: An Analytical Sourcebook with Cases. USA: Kumarian Press.

Van der Vorst JGAJ. 2006. Performance Measurement in Agrifood Supply Chain Networks : An Overview. Di dalam:
CJM Ondeersteijn, JHM Wijnands, RBM Huirne, O van Kooten, editor. Quantifying The Agri-food Supply Chain. 2006. Netherland: Springer Science Business Media. 